\title{
Managers' experiences of ethical problems in municipal elderly care: a qualitative study of written reflections as part of leadership training
}

\author{
This article was published in the following Dove Press journal: \\ Journal of Healthcare Leadership
}

\author{
Lise-Lotte Jonasson' \\ Lars Sandman ${ }^{1,2}$ \\ Anders Bremer ${ }^{1,3}$ \\ 'Faculty of Caring Science, Work Life and \\ Social Welfare, University of Borås, \\ Borås, Sweden; ${ }^{2}$ Department of Medical \\ and Health Sciences, Division of Health \\ Care Analysis, Linköping University, \\ Linköping, Sweden; ${ }^{3}$ Faculty of Health \\ and Life Sciences, Linnaeus University, \\ Växjö, Sweden
}

Background: Managers in elderly care have a complex ethical responsibility to address the needs and preferences of older persons while balancing the conflicting interests and requirements of relatives' demands and nursing staff's work environment. In addition, managers must consider laws, guidelines, and organizational conditions that can cause ethical problems and dilemmas that need to be resolved. However, few studies have focused on the role of health care managers in the context of how they relate to and deal with ethical conflicts. Therefore, the aim of this study was to describe ethical problems experienced by managers in elderly care.

Methods: We used a descriptive, interpretative design to analyze textual data from two examinations in leadership courses for managers in elderly care. A simple random selection of 100 out of 345 written exams was made to obtain a manageable amount of data. The data consisted of approximately 300 pages of single-spaced written text. Thematic analysis was used to evaluate the data.

Results: The results show that managers perceive the central ethical conflicts relate to the older persons' autonomy and values versus their needs and the values of the staff. Additionally, ethical dilemmas arise in relation to the relatives' perspective of their loved one's needs and preferences. Legislations, guidelines, and a lack of resources create difficulties when managers perceive these factors as conflicting with the care needs of older persons.

Conclusion: Managers in elderly care experience ethical conflicts that arise as unavoidable and perennial values conflicts, poorly substantiated values, and problematic organizational conditions. Structured approaches for identifying, reflecting on, and assessing ethical problems in the organization should therefore be implemented.

Keywords: manager, ethical responsibility, municipal, older person, thematic analysis

\section{Introduction}

The long-term care of older persons raises ethical questions and forces nursing staff to achieve a balance between ethical values when making decisions. ${ }^{1,2}$ Even if not directly involved in these ethical problems, elderly care managers are expected to serve as the link between the older person's desires, relatives' demands, and the staff work environment while managing conflicting interests and requirements. ${ }^{3,4}$ Problems can occur if the ethical principles guiding managers conflict with values that form the basis for elderly care, especially in cases where care is provided under different legislations and may reflect contradictory values. ${ }^{5}$ Ethical problems can
Correspondence: Lise-Lotte Jonasson Faculty of Caring Science, Work Life and Social Welfare, University of Borås, SE-50 I 90 Borås, Sweden

Tel +46334354797

$\mathrm{Fax}+46334354003$

Email lise-lotte.jonasson@hb.se 
also arise when health care facilities lack resources and expertise to provide high-quality and long-term care. ${ }^{6}$

Ethical problems can lead to moral stress among staff that is required to perform actions that come into conflict with their own sense of right and that occur in circumstances that are beyond their influence or control. ${ }^{1,7}$ Moral stress may arise when staff members feel compelled to go against the integrity of older persons dependent on care $^{2}$ or when the staff is unable to provide care that is considered necessary. ${ }^{8}$ Moral stress also affects managers, for example, when they are forced to accede to priorities within activities that are highly resource-constrained, when they observe inequalities between budget allocations and management responsibilities, and when organizational priorities are inconsistent with their own values. ${ }^{9,10}$ Moral stress thus represents a problem related to health and safety for both managers and their staff and is therefore a matter of concern and the responsibility of managers at several levels.

Causation exists between the working environment and managerial behavior. ${ }^{11}$ Manager's ability to create an agreeable working environment has a positive effect on the care environment and creates conditions for safe and high-quality care. ${ }^{12,13}$ Managers can draw attention to the importance of ethics by communicating the standards for ethical performances, acting as role models for moral behavior, and making use of rewards, while making clear that staff will be held responsible for ethical behavior and experience disciplinary consequences when appropriate. Managers who consider ethics in their leadership decisions also have a positive impact on the organization's performance and efficiency. However, it seems to be easier to theoretically describe ethical leadership than to practice it. ${ }^{14}$ To ensure that managers have adequate opportunities to promote mental and emotional health at work, they need support from politicians and senior managers. The availability of clear information about the duties and expectations of managers is an element that ultimately promotes good working and care environments. ${ }^{4,15}$

The foundation of a healthy environment and a congruent ethical climate in the workplace is intertwined with the ways in which ethical problems are handled. When provided with an appropriate ethical climate, the staff works as a team and receives support from colleagues and clear information from managers. Among the contributing factors to a positive ethical climate is the ability to provide health care based on the needs of the patients and their relatives; to achieve this, however, there is a need for procedures and guidelines to aid in the decision-making process in caring situations. ${ }^{8}$ With respect to ideal conditions for individualized health care, studies have shown the importance of linking ethical issues to health professionals' attitudes, norms, and values. Endeavors to provide individualized health care based on the needs and preferences of older persons are more likely to succeed when the ethical climate is congruous with these ideals. ${ }^{16}$

Within the context of providing nursing care for older patients, the goal is to provide individualized care based on the older persons' views of what constitutes a "good life", which means that the managers' and staff members' opinions should not be governing. ${ }^{1}$ It is also important that the staff members' focus is not just on getting the work done $^{2}$ but also on gaining the older patient's trust. Ethical, caring actions should be carried out based on a need to accomplish the primary task and to provide good health care ${ }^{17}$ The participation of older patients can be supported by the staff, whose individual perspectives can be called upon to create secure relationships. ${ }^{18}$ To assist in this endeavor, managers and the organization as a whole must provide support to the staff. ${ }^{19}$

Managers emphasize the idea that there are complex issues that require more structural and organized attention to health care ethics, including organizational limitations and the attitudes of nursing staff members. ${ }^{2}$ Managers thus need the ethical competence and ability to manage conflicts of interest, to promote ethical responsibility, and to create a healthy working environment for the staff. Unfortunately, in matters of practical ethics, many managers lack training and supervision as well as tools for systematic ethical analysis that are customized for carrying out the chief tasks. ${ }^{20,21}$

In summary, to serve as the head of an elderly care unit is complex due to the manager's various loyalties - to the older persons, to their relatives, to the staff, and to the organization as a whole. As an overall framework for these loyalties, requirements from politicians and top-level management make the manager's situation even more complex. Ethical conflicts result, and, if not handled properly, can have serious consequences for the older persons, staff, and managers.

Studies have been conducted on ethical problems in long-term care from the perspective of staff members. For clinical practice reasons, empirical research on ethical problems needs to be conducted to obtain knowledge regarding the ways in which to resolve ethical dilemmas in care practice. However, few studies have highlighted the manager's role in elderly care, and even fewer studies 
have been conducted on how managers relate to and deal with ethical conflicts. Therefore, the aim of this study was to describe the ethical problems highlighted by managers in elderly care.

\section{Material and methods Study design}

The study had a descriptive, interpretative design to analyze textual data from two examinations in leadership courses for managers in elderly care: "National Value Framework for Older Persons" and "To Understand and Lead from the National Value Framework for Older Persons." The data consist of written exams from identical tasks within both courses.

\section{Setting}

The settings were elderly care organizations in the south of Sweden and one university in which the leadership courses were held. Swedish elderly care is governed by the Social Service Act (SFS 2001:453) ${ }^{22}$ and the Health Care Act (SFS 2017:30). ${ }^{23}$ According to these laws, older persons have the right to receive adequate societal support and assistance. Responsibility for the health and social care of older persons, including contact with physicians and acute care, rests with municipalities and county councils.

The purpose of Swedish elderly care is to ensure that older persons are able to live a good-quality, secure, and independent life with care that is tailored according to individual needs and preferences. The national values for elderly care, which apply to all municipalities and activities, specify that each elderly person should live a life of dignity and well-being, according to the Social Services Act $(2001: 453){ }^{22}$ Older people should also have the opportunity to participate in meaningful activities in community with others. ${ }^{5}$ Managers are charged with safeguarding these norms while responding to organizational demands for efficiency and cost-effectiveness. ${ }^{24}$

\section{Participants}

The two leadership courses were conducted on behalf of the Swedish National Board of Health and Welfare. The majority of participants were female, middle-aged unit managers in publicly operated elderly care facilities (Table 1). The experience as a manager $(n=309)$ was 11 years (Mdn), while the experience as a manager in elderly care $(n=305)$ was 9 years $(M d n)$. The experience as a manager in the current workplace $(n=308)$ was 4.5 years
(Mdn). The majority of participants had specific areas of responsibility within elderly care $(n=131)$ and/or homeservice group/s $(n=128)$. The managers were responsible for specific patient groups; people with dementia $(n=69)$, short-term residents $(n=52)$, home health care patients $(n=35)$, and patients participating in daytime activities $(n=35)$. Other responsibilities included rehabilitation, psychiatry, management, assistance, dementia-team service, staffing/support functions, and night patrol.

\section{Data collection}

A simple random selection ${ }^{25}$ of 100 out of 345 written exams was made to obtain a manageable amount of data. The selection was made in the two courses and from the total population of students and managers. The courses took place from autumn 2012 through spring 2014. The data consisted of approximately 300 pages of singlespaced written text. The first task in the written exams directed students to use their own experiences in identifying and problematizing ethical problems in relation to the national value foundation for elderly care and based on the perspective of the older persons. Second, the students were instructed to suggest possible solutions to the ethical problems they stated. Only the descriptions of the ethical problems were analyzed in this study. The solutions to these ethical problems will be analyzed separately and published later.

\section{Data analysis}

Thematic analysis, a flexible method used in several qualitative studies (Braun \& Clarke, 2006), ${ }^{26}$ was used to evaluate the data. The method was used inductively (ie, data were analyzed without a predefined theoretical starting point).

The analysis was conducted in six steps: 1) The text was read and re-read several times to gain familiarity with the data corpus; 2) initial coding was performed on the entire dataset, and parts of the data answering the research questions were marked; 3) the codes were re-read, and themes were generated based on codes relevant to each other; 4) the themes were checked with the extracted codes in each written exam and the data corpus, which generated a thematic map of the analysis in each exam; and 5) themes were defined, the specifics of each theme were clarified, and a clear definition and name for the theme were determined. These texts and maps are referred together as a whole text, and a comprehensive map of all text was produced. The themes were processed, redefined, 
Table I Demographics of the total population $(\mathrm{N}=345)$

\begin{tabular}{|c|c|c|}
\hline & $\begin{array}{l}\text { Valid data, } \\
\text { n }\end{array}$ & $\begin{array}{l}\text { All } \\
\text { participants }\end{array}$ \\
\hline Gender, n (\%) & 307 & \\
\hline Women & & $292(95.1)$ \\
\hline Men & & $15(4.9)$ \\
\hline Age (year), n (\%) & 313 & \\
\hline$\leq 34$ & & $15(4.8)$ \\
\hline $35-44$ & & $80(25.6)$ \\
\hline $45-54$ & & 140 (44.7) \\
\hline$\geq 55$ & & $78(24.9)$ \\
\hline Function, n (\%) & 319 & \\
\hline Unit manager & & $260(81.5)$ \\
\hline Operation manager & & $37(11.6)$ \\
\hline $\mathrm{MRN}^{\mathrm{a}}$ and $\mathrm{MRRA}^{\mathrm{b}}$ & & $2(0.6)$ \\
\hline Social services manager & & $3(1.0)$ \\
\hline Other function & & $17(5.3)$ \\
\hline $\begin{array}{l}\text { Ownership of care facility, } n \\
\text { (\%) }\end{array}$ & 317 & \\
\hline Private & & $4 I(12.9)$ \\
\hline Municipal & & $276(87.1)$ \\
\hline County population size, $\mathrm{n}(\%)$ & 305 & \\
\hline Small $(<20000)$ & & $106(34.8)$ \\
\hline Medium (20 000-50 000) & & $72(23.6)$ \\
\hline Large (50 000-100 000) & & $48(15.7)$ \\
\hline Larger (>100 000) & & $79(25.9)$ \\
\hline $\begin{array}{l}\text { Subordinated employees, } n \\
\text { (\%) }\end{array}$ & 345 & \\
\hline $1-14$ & & $22(6.4)$ \\
\hline $15-29$ & & $67(19.4)$ \\
\hline $30-44$ & & $127(36.8)$ \\
\hline $45-59$ & & $69(20.0)$ \\
\hline$\geq 60$ (Range 60-II0) & & $60(17.4)$ \\
\hline $\begin{array}{l}\text { Education in management, } n \\
\text { (\%) }\end{array}$ & 297 & \\
\hline Single course & & $33(11.1)$ \\
\hline Upper secondary school & & $19(6.4)$ \\
\hline
\end{tabular}

(Continued)
Table I (Continued).

\begin{tabular}{|l|l|l|}
\hline & $\begin{array}{l}\text { Valid data, } \\
\mathbf{n}\end{array}$ & $\begin{array}{l}\text { All } \\
\text { participants }\end{array}$ \\
\hline University & & $245(82.5)$ \\
\hline $\begin{array}{l}\text { Primary profession (exam), } \mathrm{n} \\
\text { (\%) }\end{array}$ & 202 & \\
\hline Bachelor of social work & & $30(14.9)$ \\
\hline Psychologist & & $1(0.5)$ \\
\hline Registered nurse (RN) & & $69(34.2)$ \\
\hline Social-care exam & & $74(36.6)$ \\
\hline Occupational therapist & & $13(6.4)$ \\
\hline Physiotherapist & & $5(2.5)$ \\
\hline Human resources specialist & & $10(5.0)$ \\
\hline Work and function area, $\mathrm{n}(\%)$ & 257 & $132(51.4)$ \\
\hline Social care & & $101(39.3)$ \\
\hline Healthcare & & $24(9.3)$ \\
\hline Personnel and administration & & \\
\hline
\end{tabular}

Notes: ${ }^{a}$ Medically responsible nurse. ${ }^{b}$ Medically responsible for rehabilitation activities.

and clarified once more in order to obtain fewer distinct themes. The final step, 6), was to generate the report and present the themes and a coherent pattern, both of which were supported by quotes from the exams. ${ }^{26}$ The analysis was led by the first author. The codes and themes were then discussed and agreed upon by all the researchers. This manner of analysis strengthens the validity due to the researchers' approach to investigating, checking, questioning, and theorizing the data, coding, and themes. ${ }^{27}$

\section{Ethical considerations}

Informed consent was obtained through an opt-out method, ie, all informants were given information about the study and about the opportunity to notify the researchers if they did not wish to participate. According to Swedish legislation, however, the written exams and other course content are public information. Since the examination data contains sensitive personal data, it was made anonymous. The data were stored in such a way as to make it inaccessible to unauthorized persons, and all data were handled confidentially. The study complied with the ethical principles for research within Swedish law (SFS 2003:460). ${ }^{28}$ 


\section{Results}

\section{Ethical conflicts in relation to older persons' autonomy and values}

Management in elderly care involves ethical conflicts that need to be addressed. Managers perceive that the conflicts are about autonomy versus the needs of the older persons and about the circumstances under which needs are negotiated between stakeholders and in relation to the older persons' values.

\section{Ethical conflicts in relation to autonomy}

Managers describe the older person's self-determination in different ways, observing that nursing staff members take varied approaches to the self-determination of older persons. Situations are found problematic with regard to who should make decisions and different aspects of the decision-making process. Managers perceive the older person's autonomy as endangered. The situations involve both respect and disregard for the older person's autonomy, which means ethical problems for managers and consequences for the older person's perceptions of security, meaningfulness, and participation.

The older person's privacy and self-determination are perceived to be opposed to nursing staff's concerns about the consequences of the older person's own choices. When situations arise in which older persons are left uninformed, their ability to exercise their autonomy becomes limited. Sometimes, older person asserts their independence while at the same time being dependent on help from others; in these instances, the older persons feel offended when requests are overlooked by the staff.

Ethical problems occur even when the older person has requests, such as a desire to receive care from a particular staff member or changing staff. Managers perceive that such requests create concern and opposition among the staff. Instead of having their wishes respected, the older patients are often pressured toward adaptation through staff procedures and a lack of understanding, even though care interventions often are conducted in the older person's own home. Managers perceive the staff as performing their tasks in an unreflected manner by failing to reflect on the older person's autonomy.

Given the reduced ability to assert their autonomy that sometimes comes with age, older people are particularly vulnerable. It happens that routines preferred by older people are interrupted when problems with staffing schedules arise. For example, walks are canceled, meals are provided at different times, and there may be less assistance with hygiene shifts. Staff members commented: "The older person still does not complain" and "Patient X's relatives get annoyed that the older person does not have a specific action performed at a certain time, so the older people tend not to complain about experiencing reduced levels of care resulting from scheduling changes" (Participant 60).

It can be difficult to receive help without feeling offended. A manager described how a male nurse, simply because he is a man, violates an older woman when aiding with personal care and toileting. The choice of the male caregiver is made purely on the basis of staff's perceptions of professionalism since the caregivers "think it is convenient that anyone who knows the language helps the woman" (Participant 89).

\section{Older persons' actions that negatively affect others}

Managers described ethical conflicts between the older person's individual autonomy in relation to other people's privacy and autonomy. Actions by one person must not be allowed to harm another person. For example, a conflict described by a manager occurred between older residents during lunch at a care facility. Believing that the situation had gone too far, one of the staff members intervened and reprimanded one person in front of the others, causing the censured person to become deeply offended. The problem was amplified by the fact that the relatives involved wanted the older person to continue eating with the other residents, even though it was against the residents' wishes.

The managers also encounter conflicts relating to an older person's actions against the staff. Staff members expressed concerns about being beaten, harassed, spat at, and subjected to insults, all of which lead to incident reports and occupational disease notifications that then have to be handled by the managers.

\section{Ethical conflicts in relation to the relatives' perspective}

Relatives play a central role in elderly care. Their presence can lead to ethical conflicts managers, being caught between relatives, staff, and the older person's perceptions, have to deal with. Moreover, managers are expected to take a stand on ethical conflicts and to resolve them.

\section{Relatives' perceptions of older people's needs versus staff's preferences}

Managers experience ethical conflicts between the staff's preferences for providing care and the relatives' perceptions 
of the older person's health and social care needs. A manager gave the following example: "Staff felt that there was a high risk of falls and a risk of injury to the staff, so they took one sit-to-stand lift away and replaced it with another lift. This led to a big protest by relatives, who became very upset because they felt that the staff had acted disrespectfully and against the patient's will." (Participant 72)

Relatives have knowledge about the older person's past life and values, which often form the basis for their perceptions about the person's care needs. This is sometimes the basis for the staff's willingness and obligation to respect the older person's autonomy. Distinct values might be linked to the different meanings of security, depending on the perspective and whether it is staff or relatives describing the older person's situation. Relatives can believe that the older person is unsafe, while the staff feels that he or she is safe, and vice versa.

\section{Relatives' conflicting perceptions of the older person's care}

Managers describe how the older person's autonomy and dignity may conflict with relatives' different perceptions of the older person's best interests. In these situations, there is often confusion among staff about who can and must represent the older persons. As a result, the relatives' perceptions and actions present managers with difficult situations in which their role and the facility's own mandate seems unclear.

\section{Ethical conflicts between the older person's needs and staff's values}

Managers face ethical conflicts that affect the extent to which the needs of elderly patients are met. Value conflicts within and between working groups are influenced by the prevailing culture in the groups. These conflicts imply a risk that the older person's needs may be neglected.

\section{Cultural values and work patterns among staff versus} the older person's wishes and needs

According to the managers, a focus on patient safety by staff members may at times conflict with the focus of other staff members on the older person's self-determination and privacy. It is also possible for the older person's autonomy to conflict with the staff's work routines.

Working in the field of elderly care puts significant demands on staff skills and flexibility. When staff must deal with matters relating to the individual older person's actions, courage is needed to decide if and when actions should be carried out, who will perform the action, and how the action should be performed. Decisions sometimes emanate from the staff, rather than the older person, perspective can result in consequences in terms of quality reductions in the care of other patients who also are dependent on the staff's schedule. In such circumstances, it is hard to create an open climate in which the older person is involved and where comments and complaints are received positively and constructively, as a part of a continuous improvement process. Managers therefore stress the importance for staff to counter their own assumptions about their older patients' wishes by getting to know them and encouraging their participation in the decision-making process.

Managers experience ethical conflicts between rigid working-group cultures and other staff who have the willingness and ability to meet the needs of older persons. Some working groups develop a pattern in which the older person is neglected because respect between staff members in the working group takes precedence. Staff members sometimes choose each other's company instead of creating close relationships with the person. A manager believes that such working groups "develop a practice of team spirit on the basis of their own rules and 'socialize' new members into these rules so that they have a rather uncritical relation to them" (Participant 86).

\section{Disagreement on the needs of older persons}

Managers described that ethical issues arise when staff members view the needs and expressed wishes of the older persons differently. There is disagreement between staff groups on what is in the older person's best interest or autonomous will. Professional perspectives end up in opposition to each other. For example, the staff members' different perspective on the nocturnal supervision of the older person induces the nurse in charge to order inspections of all the persons regardless of their needs. Another ethical problem occurs when the nursing focus shifts within a working group. A common example is a situation in which some health care professionals in the working group have their focus on caring and on the older person's needs, which prompts them to work on a person-centered basis, while others in the working group do not appear to see the needs of the older persons.

\section{Ethical conflicts in relation to legislation, guidelines, and inadequate resources}

Applications of laws and regulations constitute a source of ethical problems. Managers' uncertainty regarding the 
application is reflected in difficulties in prioritizing between people's needs and rights, determining the limits of responsibility between professions and organizations, conflicting value systems, and the ability to provide equal and fair care.

\section{Contradictions of legislation versus the needs of older persons}

Ethical issues arise for managers when they perceive that laws, such as the Social Services Act, the Health Care Act, and the Work Environment Act, collide. Managers of elderly care are responsible for practices, economics, and employees. Issues that arise include how managers should give priority to the older person's needs and well-being in relation to the staff's working environment. The manager has a duty to meet the needs of older individuals with an awareness of relevant health and safety legislations, particularly in terms of what they require in terms of protecting the health of staff members. All too often, managers are unsure as to how they should interpret the laws, such as how to approach the care of older people with dementia without active consent of the person him/herself. There is also uncertainty about a relative's mandate to make decisions on behalf of the older person. The Social Service Act generally demands informed consent with respect to social care and support; in reality, however, such care and support must be provided when the manager perceives the application of informed consent to be difficult.

Managers also encounter ethical conflicts when an unclear professional and organizational responsibility may conflict with the older person's best interests. This conflict becomes particularly apparent when an older person's condition is life-threatening as well as when multiple instances are involved and uncertainty arises about which organization is responsible (eg, whether it is the responsibility of the municipality or the county council). The manager's dilemma has several aspects: their mandate in relation to the assessments made by professionals, their impulse to act when the older person's best interests seem to be in danger, and their support of legislation by arguing for the decisions and actions that the manager takes.

Managers in elderly care are also faced with conflicts related to local conditions that are in conflict with the spirit of the law. Following the Social Service Act, the older person's needs are central, which is sometimes perceived to be contradictory to a local, standardized range of actions.

Managers feel that the organization requires efficiency, resulting in restrictions for the older persons and a conflict for the manager when he or she feels that the care unit cannot live up to the set requirements and objectives while following ethical norms and values. It has been widely observed that older persons experience limited freedom and quality of life, conditions that are reflected in fewer choices, less influence, and weakened self-determination. These factors are understood as barriers that prevent people from living dignified and happy lives and to experience well-being. Managers expressed concern over resource constraints: "How much more efficient can we be?" (Participant 93). Managers' direct concerns toward their superiors are about the consequences of inadequate resources and how the core values of health care, including long-term care, are affected by the restrictions. One manager asked himself: "Empowerment, self-determination, personalization: Is there a limit?" (Participant 93).

Increasingly, resource issues play a dominant role in elderly care. The managers provided examples of how the financial control system ignores the needs of older persons. One example is the reimbursement system, in which home service revenues are generated for a granted time for a single person; this process is known as performancebased compensation. Similarly, low staffing levels result in the needs of older people not being met or that planning systems for staff distribution worsen the continuity of care.

\section{Conflicting value systems between organizational levels}

The goal is to give older persons good care from a holistic perspective. For managers, this is perceived as a dilemma when staff and managers at various organizational levels interpret the same values in different ways. These differences are especially clear when comparing the official values of the care unit and those of the staff. Confusion about the official values at various levels creates ethical dilemmas. Based on the managers' experience, the municipalities often formulate values contrary to the national values. Hence, when a value system is perceived as contradictory, managers are faced with difficult choices. A manager took a clear position: "In my world, it's the national value foundation and the activities that must come up with the basis of how we are going to work on this" (Participant 69).

When staff members are not grounded in the same core values, ethical conflicts arise, which may be characterized as personal and/or professional value conflicts. Varying approaches based on different values can create insecurity and confusion among older persons. According to the managers, ethical conflicts arise when there is uncertainty about which stakeholder in the care dynamic has the right 
to decide about the care and treatment of older persons. The ethical conflict is clarified when values that managers perceive as relevant are not reflected in the staff's behavior and approach within and between groups of employees as well as to the older person in need of care and attention.

\section{Discussion}

The results of the present study show that managers in elderly care experience ethical conflicts arising in the form of Unavoidable and perennial value conflicts, Poorly substantiated values, and Problematic organizational conditions.

Unavoidable and perennial value conflicts are those that involve the older person's autonomy and individual needs and how health professionals deal with these problems. They are unavoidable and perennial in that they have always occurred and are likely, in general, to always occur in the care setting. Problematic ethical situations emerge when older people act disrespectfully toward one another. Similarly, ethical conflicts concerning behavior arise between professionals and relatives and their perceptions of the older person's needs.

Poorly substantiated values indicate conflicts based on the managers' experiences of the professionals' views of health care and of long-term care for the older person that are not in line with norms in the staff group, in other professional groups, or in relation to more generally established norms.

Organizational conditions deal with the needs of older people in relation to available resources and other organizational conditions (eg, legislation). These vary case by case, and a characteristic, reasonable response with respect to the manager's role and tasks varies depending on the basis and character of the conditions.

\section{Unavoidable and perennial value conflicts}

The results show that managers are confronted with ethical conflicts that are perennial within health and social care and which likely cannot be avoided but rather occur when a person needs care, and another person provides the care. Such conflicts generally need a balancing of different values in which not all can be optimally realized. However, it is important to emphasize that not all ways to balance such values can be ethically justified. In general, the conflicts relate to the older person's autonomy and how health professionals' approach this, which occurs in congruence with the effect of the professionals' own definitions of autonomy. When guiding health professionals, managers need courage to protect the older person's autonomy and respect their desires, regardless of whether they conflict with one's own values. Managers might face reluctance toward, or respect for, the older person's autonomy or value conflicts involving different definitions of autonomy. A manager who practices ethical leadership has been described as one who deliberately focuses on fundamental values and motivates employees to maximize their potential. ${ }^{29}$ In elderly care, managers need a solid competence in nursing leadership to balance multiple demands and for the good of all stakeholders. ${ }^{30}$ If staff members perceive that their own work situation is affected by satisfying the older person's desires, as indicated in the present results, it may be viewed as a reason to ignore the older person's autonomy or for the staff to demand that limits be placed on the patients' autonomy. The question, however, is if and when it is desirable and ethically defensible to apply such limits. This way to portray the conflict might indicate that the staff and the older persons are involved in a conflict between autonomous equals, requiring a balancing of their individual interests. However, the older person in need of care is dependent upon the staff. In the words of Arman and Rehnsfeldt (p 374) "[the] asymmetry is obvious in that the patient is in need and caregivers are in possession of the healing and alleviating resources". ${ }^{31}$

To decrease suffering, managers have a duty to provide conditions that encourage and nurture care for patients. ${ }^{32}$ This should include clarifying the asymmetric role of the carer in relation to the older person and important preconditions for a caring approach, eg, a holistic view of the person, identifying their needs and responding to them, allowing yourself to be touched by the person, sometimes doing the "little extra" to confirm this approach. ${ }^{31}$ However, it is also important for the manager to clarify where "the buck stops", ie, the limits of professional responsibility.

The driving force for staff should be to provide good care, but circumstances sometimes require priorities. The study found that shortages of professional caregivers force the need to prioritize the care needs of the older patients, a situation which has been found to be a cause of moral stress. ${ }^{1,7}$ In such cases, the manager can support professionals by raising awareness of the need to prioritize and develop a climate of openness and dialogue with which to manage the everyday moral issues in elderly care. This can be a learning experience, built on the respondents' own experiences, for the involved professionals and managers. ${ }^{2}$ Managers who embody such leadership have insights into people's values and understand the motives behind human 
behavior. ${ }^{29}$ In a health care organization where staff members are valued, leadership focuses on fundamental ethical values, and employees are motivated to maximize their abilities, a healthy working environment can be promoted and also, indirectly, the well-being that is central to appropriate care for older persons. ${ }^{8,16,33}$

\section{Poorly substantiated values}

The results show that managers experience ethical conflicts that seem to be caused by value conflicts, expressed as poorly substantiated values among staff members in relation to the older persons and their relatives. Examples include working groups that do not recognize the needs of the older person or professional perspectives that are in contrast to established ethical norms.

In these conditions, staff members create their own rules and sometimes choose each other's company instead of fostering relationships with the older patients. In essence, this seems to reflect lack of a caring approach to the older person. Once again, this indicated not "seeing" the whole persons and their needs, responding to them as individuals - thereby risking increasing their suffering or problems. ${ }^{34}$ This can create conflicts and unhelpful attitudes in the staff group. The manager's role is to draw attention to the caring role of the staff but also to create beneficial conditions that will enable professionals to effectively handle these internal conflicts. One way to create such conditions and ensure that management is appropriate is to produce generic routines. ${ }^{4}$ However, routines might only set a basic necessary lowest standard, to actually care for the older persons might require a responsive attitude in the staff going beyond the following of routines or guidelines. ${ }^{35,36}$ For example, the manager, together with the professionals, conducts regular ethics meetings that focus on everyday ethical challenges and on the development of a systematic approach for dealing with ethical dilemmas. However, such meetings might also stimulate the development of ethical attention and awareness, developing a more caring approach ${ }^{37}$ (see below) Additionally, the older persons and their relatives can be invited to attend these ethics meetings. ${ }^{38}$ Many unnecessary conflicts may be avoided if the focus is on the older persons' needs, and if a good dialogue is established with them and their relatives so that relevant information can be shared. ${ }^{39}$

Managers have a responsibility for security and good health at work, which also includes the requirement to understand how one's own behavior can promote a good work environment. ${ }^{11}$ Our results raise the question of whether the moral character of health professionals and group norms can be developed. When professionals overlook older persons' opinions or fail to meet their needs and desires, the manager has the responsibility to address these concerns and provide guidance and support to the staff. Research has shown that such support can take the form of regular reflection. ${ }^{40-42}$ This may be the way to strengthen the ethical competence of professionals and to engage the older person in a caring relationship so that he or she experiences a feeling of "at-homeness." The feeling of "being home" has significance in terms of the older person's health and well-being. ${ }^{40}$ Regular reflection can also reduce or prevent moral stress. ${ }^{43}$ However, it is important to consider that support for the staff should not be based on the manager's preunderstanding but instead on genuine knowledge in caring and with a compassionate and humble approach to the staff. This means, for example, to recognize ethical values that guide nurses in their caring encounters with older patients. ${ }^{44}$ It also means a need to create conditions for staff and nurses to provide care that focus on the person in need of integrity and selfdetermination based on corroborating, ie, support and interaction. ${ }^{45}$ In essence, managers need to recognize caring as an interpersonal relationship that is the essence of caring, manifested as supportive relationships with older persons. ${ }^{46}$

Excessive staff workloads and stress can negatively affect concentration, which in turn can lead to adverse effects on patient safety. ${ }^{47}$ Moreover, professionals' selfchecks of their workloads positively affect their well-being and work satisfaction. ${ }^{48}$ It has been argued that health care professionals have a greater motivation and willingness to make efforts in health care and nursing services if they believe in the management. ${ }^{49}$ A contributing factor toward building such trust is a clear and present type of management that enhances cooperation between different professions. $^{30}$

Because staff members differ in their behavior and beliefs related to care situations and activities, a more reflective approach is advisable as a way to deal with ethical issues that are central in elderly care. Making use of self- and group-reflection leads to more effective coping strategies for team members. ${ }^{41}$ It can also be a way to give caregivers better support and the ability to handle complex situations. Subsequently, the use of staff experiences to improve complex situations may lead to improved treatment among older people and their relatives. ${ }^{50}$ Also, reflection in the group has impact at the individual level when professionals learn from each other. $^{41}$ 


\section{Organizational conditions}

The manager has the responsibility for operations with the task of implementing political decisions, translating societal values, and acting as the bearer of ethical values. ${ }^{3}$ However, as found in this study, when various levels of the organization interpret the same national values in different ways, this causes managers to face ethical dilemmas. In other words, the manager is in a middle position with politicians and overall managers and their requirements on the one hand, and health care professionals, the older persons and their relatives and requirements on the other hand. ${ }^{3,4}$ At the same time, managers have different sources for their own ethical reflection: the professional ethics given their professional background, their personal ethical values and norms, and their experience from managerial duties. Here, five key factors for high-performance leadership are applicable: accountability, communication, vision, dedication, and leadership qualities. ${ }^{50}$ Managers are usually aware that they are responsible for setting standards and for incorporating shared ethical values. ${ }^{4}$ This role includes guidance on the trade-offs and borders and the need to work with lawmakers. Available resources constitute an organizational factor that necessarily restricts care. Resource constraints lead to the need for tradeoffs among different values, and there is no care context without some resource constraints. A solution to this problem is to allow resource priorities to be explicitly guided by ethical values, such as those found in the Swedish law. ${ }^{23}$ However, the managers in our study at times experienced resource constraints that were so severe that their ability to provide care consistent with ethical values was significantly affected. If an important aspect of caring and alleviation of suffering is to provide "the little extra" for persons in care, ${ }^{31}$ and resources are not found to be enough to provide more basic necessary care following national guidelines - managers might experience moral stress. This might then be viewed as a case of conflicting messages from the political level—setting up ethical standards but not providing the means to live up to these standards. It also raises questions on to what extent there is a managerial duty to "fight" for more resources for the persons within their care - and how this should be balanced against equal care nation-wise.

\section{Conclusion}

Managers in elderly care have the responsibility to effectively handle the older person's desires, relatives' demands, and staff work environment as well as laws and guidelines, while addressing conflicting interests and requirements.
There are central ethical conflicts that involve the older persons' autonomy and values in addition to conflicts between the older persons' needs and staff members' values. Additional dilemmas relate to the relatives' perspective and ethical dilemmas linked to legislation, guidelines, and inadequate resources. These results lead managers in elderly care to experience ethical conflicts that arise in the form of unavoidable and perennial value conflicts, poorly substantiated values, and problematic organizational conditions. A solution to these problems is to allow resource priorities to be explicitly guided by ethical values and leadership that comprises accountability, communication, vision, dedication, and leadership qualities. The managers have their own professional ethics, which they trust when faced with an ethical dilemma, but they also have a set of ethics that is based on their own core values and the experience gained from their managerial duties.

\section{Acknowledgment}

The authors want to thank the managers for taking an active interest in participating in the study.

\section{Disclosure}

The authors report no conflicts of interest in this work.

\section{References}

1. Ågren-Bolmsjö I, Edberg AK, Sandman L. Everyday ethical problems in dementia care: a teleological model. Nurs Ethics. 2006;13(4):340359. doi:10.1191/0969733006ne890oa

2. Dauwerse L, van der Dam S, Abma T. Morality in the mundane: specific needs for ethics support in elderly care. Nurs Ethics. 2012;19(1):91-103. doi:10.1177/0969733011412102

3. Ekholm B. Middle managers in elderly care under demands and expectations. Leadersh Health Serv. 2012;25(3):203-215. doi:10.1108/17511871211247642

4. Dellve L, Wolmesjö M, editors. Ledarskap i äldreomsorgen: Att leda integrerat värdeskapande $i$ en röra av värden och förutsättningar [Leadership in elderly care: leading integrated value creation in a mess of values and conditions]. Borås: University of Borås, Sweden; Vetenskap för profession; 2016:35. Swedish.

5. Bergman A. Att Leda Inom Äldreomsorgen - En Litteraturgenomgång Av Enhetschefers Organisatoriska Sammanhang Och Arbetsvillkor [To Lead in Elderly Care - A Literature Review of Unit Managers' Organizational Contexts and Working Conditions]. Karlstad: Karlstad University, Sweden; Karlstad University Studies; 2009:8. Swedish.

6. Gjerberg E, Førde R, Pedersen R, Bollig G. Ethical challenges in the provision of end-of-life care in Norwegian nursing homes. Soc Sci Med. 2010;71(4):677-684. doi:10.1016/j.socscimed.2010.03.059

7. Silén M, Svantesson M, Kjellström S, Sidenvall B, Christensson L. Moral distress and ethical climate in a Swedish nursing context: perceptions and instrument usability. J Clin Nurs. 2011;20(2324):3483-3493. doi:10.1111/j.1365-2702.2011.03753.x

8. Silén M. Encountering Ethical Problems and Moral Distress as a Nurse: Experiences, Contributing Factors and Handling [dissertation]. Jönköping: Jönköping University; 2011. 
9. Mitton C, Peacock S, Storch J. Moral distress among healthcare managers: conditions, consequences and potential responses. Health Policy. 2010;6(2):99-112.

10. Storch J, Schick Makaroff K, Pauly B, Newton L. Take me to my leader: the importance of ethical leadership among formal nurse leaders. Nurs Ethics. 2013;20(2):150-157. doi:10.1177/0969733012474291

11. Jiménez P, Winkler B, Dunkl A. Creating a healthy working environment with leadership: the concept of health-promoting leadership. Int $J$ Hum Resour Man. 2017;28(17):2430-2448. doi:10.1080/ 09585192.2015.1137609

12. Davenport LJ, Allisey AF, Page KM, LaMontagne AD, Reavley NJ. How can organisations help employees thrive? The development of guidelines for promoting positive mental health at work. Int $J$ Workplace Health Man. 2016;9(4):411-427. doi:10.1108/IJWHM-01-2016-0001

13. Aitamaa E, Leino-Kilpi H, Puukka P, Suhonen R. Ethical problems in nursing management: the role of codes of ethics. Nurs Ethics. 2010;17(4):469-482. doi:10.1177/0969733010364896

14. Brown ME. Misconceptions of ethical leadership: how to avoid potential pitfalls. Organ Dyn. 2007;36(2):140-155. doi:10.1016/j. orgdyn.2007.03.003

15. Abdelrazek F, Skytt B, Aly M, El-Sabour MA, Ibrahim N, Engström M. Leadership and management skills of first-line managers of elderly care and their work environment. J Nurs Manag. 2010;18 (6):736-745. doi:10.1111/j.1365-2834.2010.01132.x

16. Suhonen R, Stolt M, Gustafsson ML, Katajisto J, Charalambous A. The associations among the ethical climate, the professional practice environment and individualized care in care settings for older people. J Adv Nurs. 2013;70(6):1356-1368. doi:10.1111/jan.12297

17. Roos C, Silén M, Skytt B, Engström M. An intervention targeting fundamental values among caregivers at residential facilities: effects of a cluster-randomized controlled trial on residents' self-reported empowerment, person-centered climate and life satisfaction. BMC Geriatr. 2016;16:130. doi:10.1186/s12877-016-0306-2

18. Ashworth PD, Longmate MA, Morrison P. Patient participation: its meaning and significance in the context of caring. J Adv Nurs. 1992;17(12):1430-1439.

19. Martin GP, Finn R. Patients as team members: opportunities, challenges and paradoxes of including patients in multi-professional healthcare teams. Sociol Health Illn. 2011;33(7):1050-1065. doi:10.1111/j.1467-9566.2011.01356.x

20. Falkenström E. Verksamhetschefens etiska kompetens: Om identifiering och hantering av intressekonflikter $i$ hälso- och sjukvården [Operations Manager's Ethical Competence: On the Identification and Management of Conflicts of Interest in Health Care] [dissertation]. Stockholm: Stockholm University; 2012. Swedish.

21. Falkenström E, Ohlsson J, Höglund AT. Developing ethical competence in healthcare management. J Workplace Learn. 2016;28(1):1732. doi:10.1108/JWL-04-2015-0033

22. SFS 2001:453. Socialtjänstlag [The Social Services Act]. Stockholm: Socialdepartementet. Available from: https://www.riksdagen.se/sv/ Dokument-Lagar/Lagar/Svenskforfattningssamling/Socialtjanstlag2001453_sfs-2001-453/.Accessed 12 May, 2019.

23. SFS 2017:30. Hälso- och sjukvårdslag [The Health Care Act]. Stockholm: Socialdepartementet; 2017. Available from: https:// www.riksdagen.se/sv/dokument-lagar/dokument/svensk-forfattnings samling/halso-och-sjukvardslag_sfs-2017-30. Accessed 12 May, 2019

24. Toren O, Wagner N. Applying an ethical decision-making tool to a nurse management dilemma. Nurs Ethics. 2010;17(3):393-402. doi:10.1177/0969733009355106

25. Polit DF, Beck CT. Nursing Research: Generating and Assessing Evidence for Nursing Practice. 10th ed. Philadelphia: Lippincott Williams and Wilkins; 2016.

26. Braun V, Clarke V. Using thematic analysis in psychology. Qual Res Psychol. 2006;3(2):77-101. doi:10.1191/1478088706qp063oa
27. Kvale S. Issues of Validity in Qualitative Research. Bromley: Chartwell-Bratt Publishing \& Training Ltd; 1989.

28. SFS 2003:460. Lag om etikprövning av forskning som avser människor [The Ethical Review Act]. Stockholm: Utbildningsdepartementet. Available from: https:/www.riksdagen. se/sv/dokument-lagar/dokument/svensk-forfattningssamling/lag2003460-om-etikprovning-av-forskning-som_sfs-2003-460. Accessed April 1, 2019. Swedish.

29. Smith CJ. Home health care leadership in a changing environment. Home Health Care Manage Pract. 1997;9(6):38-44. doi:10.1177/ 108482239700900609

30. Solbakken R, Bergdahl E, Rudolfsson G, Terese B. International nursing caring in nursing leadership - a meta-ethnography from the nurse leader's perspective. Nurs Adm Q. 2018;42(4):E1-E19. doi:10.1097/NAQ.0000000000000314

31. Arman M, Rehnsfeldt A. The 'little extra' that alleviates suffering. Nurs Ethics. 2007;14(3):372-384. doi:10.1177/0969733007075877

32. Bondas T. Caritative leadership: ministering to the patients. Nurs Adm Q. 2003;27(3):249-253.

33. Suhonen R, Stolt M, Launis V, Leino-Kilpi H. Research on ethics in nursing care for older people: a literature review. Nurs Ethics. 2010;17(3):337-352. doi:10.1177/0969733010361445

34. Öhlén J. Violation of dignity in care-related situations. Res Theory Nurs Pract. 2004;18(4):371-385.

35. Delmar C. [Trust and Authority]. Tillid Og Makt. Copenhagen: Munksgaard Danmark; 1999. Danish.

36. Løgstrup KE. The Ethical Demand. Notre Dame: University of Notre Dame Press; 1997.

37. Gustafsson C, Fagerberg I. Reflection, the way to professional development? J Clin Nurs. 2004;13(3):271-280.

38. Bollig G, Schmidt G, Rosland JH, Heller A. Ethical challenges in nursing homes - staff's opinions and experiences with systematic ethics meetings with participation of residents' relatives. Scand J Caring Sci. 2015;29(4):810-823. doi:10.1111/scs.12213

39. Croona G. Etik \& Utmaning. Om lärande av bemötande i professionsutbildning [Ethics and Challenge. Learning and Teaching Human Encounters in Professional Education] [dissertation]. Växjö: Växjö University Press; 2003. Swedish.

40. Hilli Y, Eriksson K. The home as ethos of caring: A concept determination. Nurs Ethics. 2019;26(2):425-433. doi:10.1177/ 0969733017718395

41. Jonasson LL, Carlsson G, Nyström M. Prerequisites for sustainable care improvement using the reflective team as a work model. Int $J$ Qual Stud Health Well-Being. 2014;9. doi:10.3402/qhw.v9.23934

42. Jonasson LL, Nyström M, Rydström I. Reflective team in caring for people living with dementia: a base for care improvement. Reflect Pract. 2017;18(4):435-447. doi:10.1080/ 14623943.2017.1299002

43. Kälvemark-Sporrong S, Arnetz B, Hansson M, Westerholm P, Höglund AT. Developing ethical competence in health care organizations. Nurs Ethics. 2007;14(6):825-837. doi:10.1177/ 0969733007082142

44. Jonasson LL, Berterö C. The importance of 'approaching' older people: a grounded theory. Int J Older People Nurs. 2012;7(1):29_ 36. doi:10.1111/j.1748-3743.2010.00248.x

45. Jonasson LL, Liss PE, Westerlind B, Berterö C. Corroborating indicates nurses' ethical values in a geriatric ward. Int J Qual Stud Health Well-Being. 2011;6(3):7291. doi:10.3402/qhw.v6i3.7291

46. Morse JM, Solberg SM, Neander WL, Bottorff JL, Johnson JL. Concepts of caring and caring as a concept. Adv Nurs Sci. 1990;13 (1):1-14. doi:10.1097/00012272-199009000-00002

47. Lundström T, Pugliese G, Barteley J, Cox J, Guither C. Organizational and environmental factors that affect worker health and safety and patient outcomes. Am J Infect Control. 2002;30(2):93106. 
48. Häusser JA, Mojzisch A, Niesel M, Schultz-Hardt S. Ten years on: A review of recent research on the Job Demand-Control (-Support) model and psychological well-being. Work Stress. 2010;24(1):1-35. doi: $10.1080 / 02678371003683747$

49. Reed SB. Five key attributes of leadership: engaging and motivating employees are critical obligations of healthcare leaders. Healthc Financ Manage. 2017;71:48-51.
50. Pronost AM, Le Gouge A, Leboul D, et al. Relationships between the characteristics of onco-hematology services providing palliative care and the sociodemographic characteristics of caregivers using health indicators: social support, perceived stress, coping strategies, and quality of work life. Support Care Cancer. 2012;20(3):607-614. doi:10.1007/s00520-011-1139-3

\section{Publish your work in this journal}

The Journal of Healthcare Leadership is an international, peer-reviewed, open access journal focusing on leadership for the health profession. The journal is committed to the rapid publication of research focusing on but not limited to: Healthcare policy and law;Theoretical and practical aspects healthcare delivery; Interactions between healthcare and society and evidence-based practices; Interdisciplinary decision-making;

Submit your manuscript here: https://www.dovepress.com/journal-of-healthcare-leadership-journal
Philosophical and ethical issues; Hazard management; Research and opinion for health leadership; Leadership assessment. The manuscript management system is completely online and includes a very quick and fair peer-review system. Visit http://www.dovepress.com/ testimonials.php to read real quotes from published authors. 